\title{
ANALISIS SIKAP PETANI TERHADAP PENGGUNAAN BENIH LADA PUTIH DI PROVINSI KEPULAUAN BANGKA BELITUNG
}

\author{
Cipta Yan Trimawan, Rita Nurmalina, dan Burhanuddin
}

Fakultas Ekonomi Manajemen, Institut Pertanian Bogor

EmailL: cipta.yan@gmail.com

\begin{abstract}
ABSTRAK
Provinsi Kepulauan Bangka Belitung, dikenal sebagai penghasil lada putih di pasar internasional dengan nama lada putih muntok. Salah satu upaya untuk meningkatkan produktivitas adalah melalui penggunaan biji lada putih. Benih yang paling banyak digunakan oleh petani adalah varietas Petaling 1, LDK dan Merapen. Sikap petani terhadap pemilihan benih lada putih sangat penting untuk diketahui karena mereka adalah pelaku agribisnis utama yang akan menghasilkan lada putih. Tujuan dari penelitian ini adalah untuk menganalisis sikap petani terhadap atribut biji lada putih. Penelitian ini melibatkan 60 responden petani lada putih. Analisis menggunakan multi-atribut fishbein menunjukkan bahwa sikap responden lebih memilih varietas biji lada putih Petaling 1 dibandingkan dengan varietas Merapen dan LDK.
\end{abstract}

Kata Kunci: Provinsi Babel, lada putih, multiatribut Fishbein

\begin{abstract}
Bangka Belitung Islands Province, known as a producer of white pepper in the international market with the name of muntok white pepper. One of the efforts to increase productivity is through the use of white pepper seeds. The most used seeds by farmers are varieties Petaling 1, LDK and Merapen. The farmers' attitude to the selection of white pepper seeds is very important to know because they are the main agribusiness actors that will produce white pepper. The objectives of this research is to analyze the farmers' attitude on the attributes of white pepper seeds. This research was involved 60 respondents of white pepper farmers. The analysis using fishbein multiattributes showed that the attitude of respondents prefers white pepper seed varieties Petaling 1 compared to Merapen and LDK varieties.
\end{abstract}

Keywords: Bangka Belitung Islands Province, Fishbein Multiatribut and White Pepper Seeds

\section{PENDAHULUAN}

Lada merupakan salah satu produk sub sektor perkebunan yang masuk ke dalam kategori rempah-rempah. Indonesia merupakan negara yang sangat diperhitungkan dalam perdagangan lada dunia. Menurut Faostat (2017) sejak tahun 1990an Indonesia menguasai ekspor lada dunia diikuti oleh India, Brazil, Vietnam dan China. Pada tahun tersebut Indonesia bersaing dengan India sebagai ekportir lada terbesar di Dunia. Namun pada tahun 2001-2013 Vietnam mulai menggeser posisi Indonesia sebagai eksportir utama lada dunia. Terdapat lima negara dengan luas tanaman menghasilkan lada terbesar di dunia, yaitu India, Indonesia, Vietnam, Srilanka dan Brazil. Kontribusi kumulatif kelima negara tersebut mencapai
84.35 persen dari total luas tanaman menghasilkan lada dunia.

Menurut Pusat Data dan Sistem Informasi Pertanian Kementerian Pertanian (2015) Indonesia memiliki lahan kedua terbesar (181 $607 \mathrm{Ha})$ mempunyai produksi kedua terbesar yaitu 85918 ton. Negara Vietnam memiliki lahan sebesar $46618 \mathrm{Ha}$ namun produksinya terbesar di dunia yaitu sebesar 148400 Ton. Produktivitas lada Vietnam pada kurun waktu 2009-2013 ratarata sebesar 3.18 ton/ha dan produktivitas lada Indonesia rata-rata sebesar 0.47 ton/ha. Kondisi ini sangat memprihatinkan seharusnya Indonesia dengan luas lahan yang begitu besar dapat memproduksi lada jauh lebih besar dengan meningkatkan produktivitas lada. 
Penggunaan benih unggul menjadi salah satu kunci dalam meningkatkan produktivitas tanaman dan pendapatan petani (Sudjarmoko 2013; Wahyudi \& Hasibuan 2011). Menurut Hadad dan Ferry (2011) penggunaan benih unggul bermutu merupakan 60 persen jaminan keberhasilan usaha perkebunan.

Menurut Statistik Perkebunan Indonesia Lada (2016) di Indonesia, produksi lada besar berasal dari Provinsi Kepulauan Bangka Belitung yaitu sebesar 39.69 persen. Luas areal pengembangan lada tahun 2015 di Provinsi Kepulauan Bangka Belitung mencapai 48011 Ha dengan produksi 31.408 ton yang tersebar di 6 (enam) kabupaten dan seluruhnya diusahakan oleh rakyat sehingga perannya menjadi sangat penting karena merupakan penghasilan utama bagi kehidupan petani di daerah sentra produksi lada.

Kementerian Pertanian telah melepas beberapa varietas benih unggul lada diantaranya varietas Petaling 1 yang produktivitasnya dapat mencapai 4.48 ton/ha dan varietas LDK sebesar 3.86 ton/ha. (Ditjenbun 2014), namun petani masih saja menggunakan varietas benih lokal yang belum teruji produktivitasnya. Menurut Dinas Pertanian, Perkebunan dan Peternakan Provinsi Kepulauan Bangka Belitung varietas benih lada putih yang sering digunakan petani yaitu varietas petaling 1, Lampung Daun Kecil (LDK) dan Merapen (varietas lokal).

Dalam hal penggunaan benih lada, petani merupakan konsumen benih. Sikap petani terhadap pemilihan benih lada putih sangat penting untuk diketahui karena petani merupakan pelaku utama usaha pertanian yang akan menghasilkan lada putih tersebut. Rusyadi (2014) menjelaskan bahwa hal yang menjadi pilihan utama petani dalam menentukan sikap untuk membeli benih adalah produktivitas (potensi hasil), tahan hama penyakit dan umur tanaman, daya tumbuh benih, keseragaman benih, ukuran benih, ketersediaan benih, harga beli benih, asal produksi dan label sertifikasi dari benih tersebut. Engel et al. (1994) menjelaskan bahwa untuk dapat memasarkan suatu produk ke konsumen maka diperlukan suatu analisa mengenai perilaku konsumen sehingga produk dapat terserap di tingkat konsumen.
Oleh karena itu, Pemerintah dan produsen benih harus mengetahui sikap petani terhadap hasil yang dicapai oleh benih lada yang digunakan petani. Sikap memainkan peranan utama dalam membentuk perilaku petani dalam memutuskan benih varietas apa yang akan ditanam. Berdasarkan uraian tersebut, maka tujuan penelitian ini yaitu untuk menganalisis sikap petani terhadap atribut benih lada di Provinsi Kepulauan Bangka Belitung.

\section{METODE PENELITIAN}

Daerah penelitian dalam penelitian dilakukan di wilayah Provinsi Kepulauan Bangka Belitung. Petani responden berjumlah 60 orang, merupakan petani pemilik dan pernah menggunakan benih lada putih varietas Petaling 1, LDK (Lampung Daun Kecil) dan Merapen. Metode analisis yang digunakan dalam penelitian ini adalah analisis multiatribut fishbein. Menurut Engel et al. (1994) menyatakan bahwa model sikap Multiatribut menggambarkan rancangan yang berharga untuk memeriksa hubungan diantara pengetahuan produk yang dimiliki konsumen dan sikap terhadap produk berkenaan dengan ciri atau atribut produk. Formulasi model Fishbein (Engel et al. 1994) adalah sebagai berikut:

$$
A_{0}=\sum_{i=1}^{n} b_{i} \cdot e_{i}
$$

dimana:

$$
\begin{aligned}
& \text { Ao }= \text { Sikap keseluruhan konsumen terhadap } \\
& \text { benih lada } \\
& \text { bi }= \begin{array}{l}
\text { Kekuatan kepercayaan konsumen } \\
\text { terhadap atribut ke- } \mathrm{i}
\end{array} \\
& \text { ei }= \begin{array}{l}
\text { Evaluasi kepentingan terhadap atribut } \\
\text { ke-i }
\end{array} \\
& n \quad=\begin{array}{l}
\text { Jumlah atribut yang menonjol yang } \\
\text { dimiliki obyek }
\end{array}
\end{aligned}
$$

Atribut benih lada yang akan diuji dalam penelitian ini untuk menunjukkan sikap petani terhadap atribut benih varietas Petaling 1, LDK dan Merapen terdiri dari atribut-atribut sebagai berikut Produktivitas, Tahan terhadap penyakit busuk pangkal batang, Tahan terhadap penyakit kuning, umur mulai produksi, daya tumbuh, jenis varietas, jumlah ruas, harga benih, label benih, ketersediaan benih, kemudahan akses benih. 
Setiap varietas perlu mendapat nilai kepercayaan konsumen untuk masing-masing atribut. Berdasarkan hasil akhir dan perhitungan akan diketahui penilaian sikap konsumen terhadap produk. Rentang skala yang akan digunakan digunakan disesuaikan dengan rumus sebagai berikut :

$$
\mathrm{Rs}=\frac{(m-n)}{b}
$$

Dimana :

$$
\begin{aligned}
\mathrm{Rs}= & \text { rentang skala } \\
\mathrm{m}= & \text { skor tertinggi } \\
\mathrm{n}= & \text { skor terendah } \\
\mathrm{b}= & \text { jumlah kelas (dalam penelitian ini } \\
& \text { digunakan lima kategori kelas) } \\
& \text { Berdasarkan banyaknya jumlah }
\end{aligned}
$$

responden maka nilai rata-rata terkecil yang mungkin diperoleh adalah 1 dan nilai rata-rata terbesar yang mungkin diperoleh adalah 5, maka besarnya range untuk evaluasi kepentingan dan tingkat kepercayaan adalah :

$$
\begin{aligned}
\mathrm{Rs}=\frac{(5-1)}{5} & \ldots \ldots . . \\
& =0.8
\end{aligned}
$$

Sehingga rentang skala pada tingkat kepentingan dan tingkat kepercayaan adalah sebagai berikut :

$1,00<\mathrm{x} \leq 1,80$ berarti sangat tidak penting

$1,80<\mathrm{x} \leq 2,60$ berarti tidak penting

$2,60<\mathrm{x} \leq 3,40$ berarti cukup penting

$3,40<\mathrm{x} \leq 4,20$ berarti penting

$4,20<\mathrm{x} \leq 5,00$ berarti sangat penting

\section{HASIL DAN PEMBAHASAN}

Karakteristik Responden. Karakteristik petani adalah ciri-ciri atau sifat-sifat yang dimiliki oleh seseorang petani yang ditampilkan melalui pola pikir, pola sikap dan pola tindakan terhadap lingkungannya (Mislini 2006). Berdasarkan hasil penelitian 100 persen petani lada putih berjenis kelamin laki-laki, dengan sebaran usia 42-51 tahun (sebanyak 43.33\%). Menurut Mappiare (1983), ada kecenderungan bagi seseorang yang berusia 35 tahun ke atas untuk lebih memantapkan dirinya dalam bekerja, berkenaan dengan semakin tingginya biaya hidup yang perlu dikeluarkan. Pendidikan formal petani lada putih paling banyak lulusan SD yaitu sebanyak 58.33 persen. Tingkat pendidikan berpengaruh terhadap adopsi inovasi teknologi, khususnya teknologi budidaya lada putih. Petani yang berpendidikan tinggi lebih bisa membudidayakan lada putih ke arah agribisnis, bukan sekedar pemenuhan kebutuhan rumah tangga. Sebanyak 88.33 persen responden petani melakukan usahatani lada sebagai pekerjaan utama. Sebagian besar petani lada memiliki lahan seluas 1 Ha sebanyak 76.67 persen dan lahan tersebut merupakan lahan milik sendiri. Jumlah anggota keluarga inti (anak/istri) yang ikut bekerja di usahatani lada sebanyak 1 orang dengan presentase 90 persen.

Penilaian Sikap Petani Terhadap Benih

Lada putih. Penilaian evaluasi kepentingan terhadap varietas benih lada putih 14 atribut yaitu produktivitas, ketahanan terhadap penyakit kuning, ketahanan terhadap penyakit busuk pangkal batang, umur mulai produksi, daya tumbuh, jenis varietas, jumlah ruas benih, jumlah daun benih, tanggal kadaluarsa benih, harga benih, label benih, kemudahan akses benih, stok benih (ketersediaan), dan ketersediaan demplot. Kepentingan atau evaluasi menggunakan skala dengan rentang $1=$ sangat tidak penting, $2=$ tidak penting, $3=$ cukup penting, $4=$ penting, dan $5=$ sangat penting.

Berdasarkan penilaian evaluasi kepentingan (ei) terhadap 14 atribut benih lada putih, terlihat pada Tabel 1, tingkat penilaian evaluasi menunjukkan enam atribut berada pada rentang skala sangat penting, sementara dua atribut lainnya berada dalam rentang skala penting, lima atribut lainnya berada dalam skala cukup penting. Enam atribut sangat penting adalah produktivitas (4.85), ketahanan terhadap penyakit kuning (4.83), ketahanan terhadap penyakit busuk pangkal batang (4.80), stok benih (ketersediaan) (4.60), jenis varietas (4.40) dan umur panen (4.23). Atribut daya tumbuh (3.85), kemudahan dalam memperoleh akses benih (3.78), harga benih $(3,65)$ dan label benih (3.42) termasuk dalam atribut pada rentang skala penting. Empat atribut termasuk dalam kategori cukup penting yaitu, jumlah ruas benih (3.20), ketersediaan demplot di lapangan (3.17), jumlah daun benih (2.82) dan tanggal kadaluarsa (2.63).

Tabel 1.

Penilaian Evaluasi Kepentingan (ei) atribut benih lada.

\begin{tabular}{lll}
\hline Atribut & $\begin{array}{l}\text { Skor } \\
\text { evaluasi }\end{array}$ & Kategori \\
\hline
\end{tabular}




\begin{tabular}{|c|c|c|}
\hline Produktivitas & 4.85 & Sangat pentin \\
\hline $\begin{array}{l}\text { Ketahanan terhadap } \\
\text { penyakit Kuning }\end{array}$ & 4.83 & sangat penting \\
\hline $\begin{array}{l}\text { Ketahanan terhadap } \\
\text { penyakit BPB }\end{array}$ & 4.80 & sangat penting \\
\hline $\begin{array}{l}\text { Stok benih } \\
\text { (ketersediaan) }\end{array}$ & 4.60 & sangat penting \\
\hline Jenis varietas & 4.40 & sangat penting \\
\hline Umur panen & 4.23 & sangat penting \\
\hline Daya tumbuh & 3.85 & Penting \\
\hline $\begin{array}{l}\text { Kemudahan mem- } \\
\text { peroleh akses benih }\end{array}$ & 3.78 & Penting \\
\hline Harga benih & 3.65 & Penting \\
\hline Label benih & 3.42 & Penting \\
\hline Jumlah ruas benih & 3.20 & cukup penting \\
\hline Ketersediaan demplot & 3.17 & cukup penting \\
\hline Jumlah daun benih & 2.82 & cukup penting \\
\hline Tanggal kadaluarsa & 2.63 & cukup penting \\
\hline
\end{tabular}

Produktivitas. Produktivitas merupakan atribut yang sangat penting dengan skor evaluasi 4,85. Sebanyak 85 persen petani responden menyatakan bahwa produktivitas adalah atribut dengan kategori yang sangat penting. Menurut penelitian Wicaksana (2013) menyatakan bahwa produktivitas hasil merupakan atribut yang sangat penting dalam budidaya tanaman. Menurut Ditjenbun (2014) varietas benih lada putih Petaling 1 mempunyai produktivitas 4.48 ton/hektar dan varietas benih LDK mempunyai produktivitas 3,86 ton/hektar. Menurut Saefudin (2014) potensi produksi varietas unggul tersebut bisa di atas lebih tinggi dibandingkan dengan varietas lokal yang ada. Namun, jumlah pohon masing-masing varietas unggul tersebut pada kebun induk di Balai Penelitian Tanaman Rempah dan Obat, Pusat Penelitian dan Pengembangan Perkebunan masih terbatas dan industri benihnya belum berkembang seperti pada tanaman pangan dan hortikultura. Oleh karena itu, diperlukan solusi agar varietas unggul tersebut segera dapat dikembangkan di daerah sentra lada nasional.

\section{Ketahanan terhadap Penyakit}

Kuning. Skor evaluasi ketahanan terhadap penyakit kuning memiliki skor evaluasi sebesar 4.83 (sangat penting). Tanaman lada termasuk tanaman yang sangat rentan terhadap hama dan penyakit. Jenis hama yang umumnya menyerang tanaman ini adalah kumbang lada besar, kumbang lada kecil, kepik dan ulat. Sedangkan penyakit yang menyerang adalah penyakit kuning, busuk kaki dan busuk tunggul. Penyakit kuning adalah penyakit yang susah diberantas. Tanaman yang terserang penyakit ini akan terbawa jika bagian tanaman tersebut digunakan sebagai benih. Penyebab penyakit kuning yaitu tidak terpenuhinya berbagai persyaratan agronomis serta serangan cacing halus (Nematoda) Radhophalus similis yang mungkin berasosiasi dengan nematoda lain seperti Heterodera SP, M incognita dan Rotylenchus Similis. Gejalanya menyerang akar tanaman lada, ditandai menguningnya daun lada, akar rambut mati, membusuk dan berwarna hitam. Cepat lambatnya gejala daun menguning tergantung berat ringannya infeksi dan kesuburan tanaman. Pengendalian: Pemberian pupuk kandang, pengapuran, pemupukan tepat dan seimbang.

Penurunan hasil yang disebabkan oleh penyakit ini cukup signifikan, mencapai $32 \%$. Penyakit ini disebabkan oleh keadaan yang sangat kompleks, yaitu infeksi nematoda Meloidogyne incognita, Radopholus similis, dan cendawan Fusarium oxysporum, serta rendahnya kesuburan tanah. Ketiga patogen diatas bersinergi menginfeksi tanaman lada. Nematoda $M$. incognita dan $R$. Similis menginfeksi bagian akar tanaman lada sehingga menimbulkan luka pada akar tanaman, luka tersebut akan dimanfaatkan oleh cendawan $F$. oxysporum untuk melakukan penetrasi kedalam jaringan akar tanaman lada. Di Indonesia, penyakit kuning pertama kali ditemukan di daerah Bangka oleh Van der Vecht pada tahun 1932, kemudian penyakit tersebut ditemukan juga di beberapa daerah lain seperti di Kalimantan Barat (Mustika 2005; Daras dan Pranowo 2009).

Tanaman lada yang sakit akan menunjukkan gejala di atas permukaan tanah, dan gejala di bawah permukaan tanah. Gejala penyakit kuning diawali dengan terhambatnya pertumbuhan tanaman yang terinfeksi yang akan diikuti oleh menguningnya daun-daun pada tanaman tersebut. Perubahan warna kuning pada daun tanaman yang terinfeksi dimulai dari bagian bawah tanaman, dan kemudian akan merambat ke bagian atas tanaman. Daun yang telah menguning pada tanaman lada yang terinfeksi tidak menjadi layu, namun akan menjadi rapuh, sehingga daun-daun tersebut secara bertahap akan gugur, diikuti oleh gugurnya dahan dan sulur panjat sehinga tanaman menjadi gundul dan 
mati (Harni \& Munif 2012; Shahnazi et al. 2012).

Bagian bawah tanah tanaman lada yang terinfeksi oleh penyakit kuning juga menunjukkan gejala yang khas. Akar tanaman lada yang terinfeksi akan terlihat rusak. Pada akar akan ditemui puru (bengkak) dan lukaluka nekrosis akibat serangan nematoda. Puru yang terbentuk pada akar disebabkan oleh infeksi nematoda Meloidogyne spp., sedangkan luka dan nekrosis pada akar disebabkan oleh infeksi nematoda $R$. Similis (Daras dan Pranowo, 2009).

Ketahanan terhadap Penyakit Busuk Pangkal Batang. Skor evaluasi ketahanan terhadap penyakit busuk pangkal batang memiliki skor evaluasi sebesar 4.80 (sangat penting). Ketahanan benih lada terhadap penyakit busuk pangkal batang berperan sangat penting dalam produksi lada putih. Penyakit BPB disebabkan oleh jamur Phytophthora capsici (sinonim: P. palmivora var. Piperis). Selain di Indonesia, penyakit BPB juga menjadi kendala utama produksi lada di Malaysia dan India. Jamur $P$. capsici dapat menyerang semua umur/stadia tanaman, mulai dari pembibitan sampai tanaman produktif. Serangan yang paling membahayakan adalah pada pangkal batang atau akar karena menyebabkan kematian tanaman dengan cepat. Gejala berupa kelayuan tanaman secara mendadak (daun tetap berwarna hijau) akan nampak apabila terjadi serangan patogen pada pangkal batang. Pangkal batang yang terserang menjadi berwarna hitam, pada keadaan lembab akan nampak lendir yang berwarna kebiruan. Serangan pada akar, menyebabkan tanaman layu dan daun-daun menjadi berwarna kuning (Mulya et al., 2003).

Pada saat musim hujan, suhu udara menjadi rendah dan kelembaban tinggi serta didukung oleh adanya nutrisi yang cukup akan merangsang struktur istirahat jamur patogen tersebut untuk berkecambah. Tetesan air hujan yang jatuh ke tanah dapat membantu memindahkan propagul dari tanah ke daun yang di dekatnya sehingga memungkinkan terjadinya infeksi. Menurut Manohara dan Machmud (1986), infeksi pada daun terjadi 4 - 6 jam setelah diinokulasi dengan zoospora dan menimbulkan gejala berupa titik hitam setelah 18 - 20 jam diinokulasi. Kebun lada yang disiang bersih akan mengalami kerusakan lebih parah (50
- 80\% diserang BPB) dibandingkan kebun yang disiang terbatas (Manohara et al., 1993). Penyebaran jamur $P$. capsici selain oleh air dan angin yang terjadi selama hujan, juga dapat terbawa oleh ternak peliharaan, siput/keong, manusia, alat pertanian bekas dipakai pada tanaman sakit, bahkan dapat terbawa oleh bibit lada sehingga menjadi sumber inokulum bagi daerah pengembangan lada yang baru (Mulya $e t$ al. 1986).

Apabila terjadi kematian tanaman lada karena serangan penyakit busuk pangkal batang (BPB), maka segera musnahkan dan lakukan penyiraman fungisida berbahan aktif Copper oxychlorida atau bubur bordo. Varietas yang tidak tahan penyakit ini tentunya akan mengurangi jumlah tanaman lada yang ada sehingga produksi pasti berkurang.

Stok Benih (Ketersediaan).

Berdasarkan hasil penelitian sebesar 65\% petani responden menyatakan bahwa stok benih (ketersediaan) sangat penting dan sebesar $30 \%$ petani responden menyatakan penting dan secara keseluruhan nilai evaluasi rata-rata yaitu 4.60. Ketersediaan benih sangat penting karena benih merupakan input dasar yang paling penting dalam pertanian. Mutu benih yang baik merupakan dasar bagi produktifitas pertanian yang lebih baik. Benih merupakan salah satu faktor yang harus diperhatikan dalam budidaya tanaman, karena faktor tersebut ikut menentukan produksi. Fakta dilapangan menunjukkan bahwa ketersediaan dan penggunaan benih bermutu (dan berlabel) masih rendah. Permasalahan yang dihadapi dalam peningkatan produksi benih antara lain adalah keterbatasan ketersediaan benih sumber untuk diperbanyak oleh produsen dan penangkar benih. Persoalannya, ketersediaan benih unggul sampai saat ini masih merupakan kendala utama. Benih-benih yang diproduksi masih banyak yang belum memenuhi persyaratan yang sesuai. Hal ini turut menyulitkan kiprah agribisnis Indonesia di tingkat nasional maupun internasional.

Jenis Varietas. Berdasarkan hasil penelitian sebesar 55\% petani responden menyatakan bahwa jenis varietas benih sangat penting dan sebesar $30 \%$ petani responden menyatakan penting dan secara keseluruhan nilai evaluasi rata-rata yaitu 4.40. Varietas benih lada putih yang banyak digunakan oleh 
petani lada di Provinsi Kepulauan Bangka Belitung yaitu Petaling 1, Merapen dan LDK. Benih lada putih varietas Petaling 1 merupakan varietas unggul yang telah dilepas melalui Surat Keputusan Menteri Pertanian. Dalam hal jenis varietas benih, dua hal utama yang petani responden sangat inginkan yaitu jenis varietas yang produktivitasnya tinggi dan tahan terhadap penyakit kuning dan hal tersebut dimiliki oleh varietas Petaling 1.

Umur Panen (mulai berproduksi).

Berdasarkan hasil penelitian sebesar $43.33 \%$ petani responden menyatakan bahwa umur mulai produksi sangat penting dan sebesar $36.67 \%$ petani responden menyatakan penting dan secara keseluruhan nilai evaluasi rata-rata umur panen yaitu 4.23. Menurut BPTP Provinsi Kepulauan Bangka Belitung untuk varietas petaling 1 umur mulai berbunga sampai dengan buah masak kurang lebih 9 bulan. Semakin cepat buah lada masak maka semakin cepat juga petani panen sehingga semakin cepat juga petani mendapatkan pendapatan dari hasil panen tersebut.

Daya Tumbuh. Berdasarkan hasil penelitian nilai evaluasi rata-rata daya tumbuh benih yaitu penting (3.85). Sebesar $45 \%$ petani responden menyatakan bahwa daya tumbuh benih penting dan sebesar $35 \%$ petani responden menyatakan cukup penting. Secara umum daya tumbuh benih lada putih sampai mulai berbunga sekitar 10-12 bulan. Menurut BPTP Provinsi Kepulauan Bangka Belitung umur mulai berbunga varietas petaling 1 yaitu kurang lebih 10 bulan. Daya tumbuh benih ditentukan oleh jenis varietas, ketahanan terhadap penyakit dan sistem budidaya tanam yang baik.

Kemudahan Akses Benih. Berdasarkan hasil penelitian nilai evaluasi rata-rata kemudahan akses terhadap benih yaitu penting (3.78). Sebesar $75 \%$ petani responden menyatakan bahwa kemudahan akses benih penting dan sebesar $23.33 \%$ petani responden menyatakan cukup penting. Akses benih yang dekat dan mudah dijangkau akan memudahkan dalam hal pengangkutan dan dapat mengurangi biaya transportasi. Berdasarkan hasil proses keputusan pembelian menunjukan bahwa akses petani dalam membeli benih sangat dekat dan mudah didapat, kebanyakan jaraknya yaitu kurang dari $1 \mathrm{~km}$.

Harga Benih. Berdasarkan hasil penelitian sebesar $41.61 \%$ petani responden menyatakan bahwa harga benih penting dan secara keseluruhan nilai evaluasi rata-rata harga benih yaitu 3.65 masuk dalam rentang penting. Menurut petani responden harga tidak terlalu dipermasalahkan oleh mereka yang terpenting varietas benih yang di inginkan dan berkualitas tersedia. Hal ini dapat terlihat dari proses evaluasi pembelian, dimana petani akan tetap membeli benih walaupun benih tersebut mengalami kenaikan harga. Harga benih lada putih berkisar Rp. 7.000 sampai dengan 10.000 .

Label Benih. Berdasarkan hasil penelitian sebesar $40 \%$ petani responden menyatakan bahwa keberadaan label pada benih cukup penting dan secara keseluruhan nilai evaluasi rata-rata label benih yaitu 3.42 masuk dalam rentang penting. Benih berlabel jarang digunakan oleh petani responden dan walaupun ada jumlahnya masih terbatas. Hal ini disebabkan masih sedikitnya penangkar yang telah di bina oleh pemerintah. Mulai tahun 2012 penangkaran benih lada baru mulai bermunculan di setiap sentra produksi lada, antara lain di Kabupaten Bangka Selatan, Kabupaten Belitung dan Kabupaten Bangka Barat. Tercatat lebih kurang 8 (delapan) Penangkar Perbenihan lada yang sudah mengajukan Tanda Registrasi Usaha Perbenihan (TRUP) Tanaman Lada. Namun jumlah tersebut dirasa masih kurang dikarenakan permintaan terhadap benih lada sangat tinggi. Penangkar benih yang sudah terdaftar selanjutnya sumber benih tersebut di sertifikasi oleh instansi terkait (dalam hal ini UPTD Balai Pengawasan dan Sertifikasi Mutu Benih) dan benih yang telah disertifikasi baru bisa diedarkan ke petani lada, sehingga ketersediaan benih berkualitas memiliki kontinuitas, berkelanjutan dan diharapkan kemudian petani merasakan keunggulan dan kelebihan penggunaan benih unggul bermutu dan pada akhirnya dapat meningkatkan produksi dan produktivitas lada.

Jumlah Ruas Benih. Berdasarkan hasil penelitian sebesar $56,57 \%$ petani responden menyatakan bahwa jumlah ruas benih cukup penting dan secara keseluruhan nilai evaluasi rata-rata jumlah ruas benih yaitu 3.20 masuk dalam rentang cukup penting. Berdasarkan $S N I$ 01-7155-2006 tentang spesifikasi persyaratan mutu benih, standar untuk jumlah ruas benih lada yaitu 5-7 ruas dimana penanaman 
dilakukan dengan membenamkan bibit 3-4 ruas bagian pangkal sedangkan sisanya diikatkan pada tajar. Pada jumlah ruas tersebut, benih sudah cukup kuat untuk ditanam dan tidak mudah mati.

Ketersediaan Demplot. Berdasarkan hasil penelitian sebesar $85 \%$ petani responden menyatakan bahwa ketersediaan demplot benih di lapangan cukup penting dan secara keseluruhan nilai evaluasi rata-rata ketersediaan demplot benih yaitu 3.17 masuk dalam rentang cukup penting. Demontrstion Plot atau demplot adalah suatu metode penyuluhan pertanian kepada petani dengan cara membuat lahan percontohan agar petani bisa melihat dan membuktikan terhadap obyek yang didemonstrasikan. Demplot dapat berupa inovasi teknologi budidaya, VUB (Varietas Unggul Baru), pemupukan dan lain-lain, disesuaikan dengan demografi wilayah tersebut.

Jumlah Daun Benih. Berdasarkan hasil penelitian sebesar $66,27 \%$ petani responden menyatakan bahwa jumlah daun benih cukup penting dan sebesar $21.69 \%$ petani responden menyatakan tidak penting. Secara keseluruhan nilai evaluasi rata-rata jumlah daun benih benih yaitu 2.82 masuk dalam rentang cukup penting. Berdasarkan SNI 01-7155-2006 tentang spesifikasi persyaratan mutu benih, standar untuk jumlah daun benih 5-8 helai daun. Petani responden biasanya tidak terlalu memperhatikan mengenai jumlah daun benih yang ditanamnya.

Tanggal kadaluarsa Benih. Atribut tanggal kadaluarsa memiliki skor evaluasi ratarata 2.63 yang berarti persepsi petani responden terhadap atribut tanggal kadaluarsa adalah cukup penting. Berdasarkan hasil penelitian, petani responden jarang menggunakan benih berlabel, walaupun menggunakan benih berlabel dan tanggal kadaluarsa sudah habis, mereka beranggapan jika benih lada tersebut masih layak digunakan untuk 6 bulan ke depan dari habisnya tanggal kadaluarsa.

\section{Penilaian Kepercayaan Atribut.}

Analisis kepercayaan menggambarkan seberapa besar responden percaya suatu atribut melekat pada suatu objek tertentu. Seperti halnya dalam evaluasi kepentingan, analisis kepercayaan atribut benih lada putih varietas petaling 1, LDK dan merapen diukur dengan menggunakan skala dengan rentang 1 sampai 5. Hasil yang diperoleh dari analisis kepercayaan dan kepentingan menentukan sikap petani responden terhadap varietas benih lada putih yang diinginkan. Penilaian tingkat kepercayaan petani terhadap benih lada putih varietas petaling 1, LDK dan merapen meliputi 14 atribut sebagaimana dijelaskan sebelumnya.

Berdasarkan hasil penilaian evaluasi/kepentingan seperti terlihat Tabel 2, menunjukkan bahwa atribut yang dipertimbangkan petani responden yang utama adalah produktivitas. Hasil penilaian skor kepercayaan atribut produktivitas pada benih lada putih varietas Petaling 1 (4.60) dan benih lada putih varietas LDK (4.15)

produktivitasnya tinggi, sementara varietas Merapen (3.38) produktivitasnya cukup tinggi. Sehingga berdasarkan hasil penelitian tersebut menunjukkan bahwa petani responden meyakini bahwa produktivitas benih lada putih varietas Petaling 1 lebih tinggi dibandingkan varietas LDK dan Merapen.

Skor kepercayaan pada atribut ketahanan terhadap penyakit kuning diperoleh bahwa benih lada putih varietas petaling 1 adalah 3.52 yang berarti varietas tersebut tahan tehadap penyakit kuning. Benih lada putih varietas merapen adalah 3.32 yang berarti bahwa varietas tersebut cukup tahan tahan terhadap penyakit kuning. Pada benih lada putih varietas LDK skor kepercayaan pada atribut ketahanan terhadap penyakit kuning adalah 2.20 yang berarti ketahanan terhadap penyakit kuning rendah/rentan (tidak tahan). Sehingga berdasarkan hasil penelitian tersebut menunjukkan bahwa petani responden meyakini bahwa ketahanan terhadap penyakit kuning benih lada putih varietas petaling 1 lebih tahan dibandingkan dengan varietas Merapen dan LDK.

Skor kepercayaan pada atribut ketahanan terhadap penyakit busuk pangkal batang diperoleh bahwa benih lada putih varietas Merapen adalah 3.42 dengan kata lain varietas tersebut tahan terhadap penyakit busuk pangkal batang dan benih lada putih varietas LDK adalah 3.25 yang berarti bahwa varietas LDK cukup tahan terhadap penyakit busuk pangkal batang, sedangkan pada varietas benih Petaling 1 skor kepercayaan pada atribut ketahanan terhadap penyakit busuk pangkal batang adalah 2.52 yang berarti varietas petaling 1 ketahanan terhadap penyakit busuk 
pangkal batangnya rendah/rentan (tidak tahan). Sehingga berdasarkan hasil penelitian tersebut menunjukkan bahwa petani responden meyakini bahwa varietas petaling 1 lebih tidak tahan terhadap penyakit busuk pangkal batang dibandingkan dengan varietas merapen dan LDK.

Selanjutnya atribut benih yang dilakukan pengujian pada penelitian ini yaitu stok benih (ketersediaan), skor kepercayaan atribut stok benih pada benih lada putih varietas Petaling 1 (4.53) dan merapen (4.55) yang sangat tinggi/tersedia. Sementara benih lada putih varietas LDK (3.95) stok benihnya cukup tinggi/tersedia. Sehingga berdasarkan hasil penelitian tersebut menunjukkan bahwa petani responden meyakini bahwa stok benih lada putih varietas Petaling 1 dan Merapen sangat tinggi/tersedia dibandingkan dengan stok benih varietas LDK. Untuk atribut jenis varietas, skor kepercayaan varietas petaling 1 merupakan yang tertinggi yaitu (4.35) yang berarti petani responden sangat percaya terhadap jenis varietas ini.

Skor kepercayaan pada atribut umur panen diperoleh bahwa benih lada putih varietas Petaling 1 adalah 4.12, LDK sebesar 4.17 dan merapen sebesar 3.90 dengan kata lain ketiga varietas tersebut memiliki umur panen (mulai produksi) yang cukup tinggi/cepat yaitu berkisar $6.5-11$ bulan menurut petani responden. Dan skor kepercayaan untuk atribut daya tumbuh benih, varietas petaling 1 termasuk dalam kategori tinggi/cepat daya tumbuhnya menurut petani responden. Daya tumbuh varietas petaling 1, LDK dan Merapen yaitu berkisar 7-11 bulan. Dalam hal skor kemudahan dalam akses benih lada putih, varietas petaling 1 , LDK dan Merapen akses petani responden dalam memperoleh benih tersebut sangat mudah. Jarak petani responden dalam mendapatkan benih tersebut berkisar 1-5 km dari tempat tinggalnya.

Berdasarkan hasil penelitian pada skor kepercayaan atribut harga benih lada putih varietas petaling 1 yaitu sebesar 3.30 yang berarti menurut petani responden harga benih varietas petaling 1 cukup mahal. Hal ini dikarenakan produktivitas dari varietas ini sangat tinggi sehingga berpengaruh terhadap harganya menjadi cukup mahal. Sedangkan skor kepercayaan harga benih varietas LDK yaitu 3.42 dan varietas merapen yaitu 3.65 yang berarti harga benihnya murah menurut petani responden. Berdasarkan hasil wawancara dengan petani, harga benih lada putih berkisar Rp. 7000-10000.

Berdasarkan dari penilaian sikap terhadap benih lada putih varietas petaling 1 , LDK dan merapen tersebut, menunjukan bahwa sikap petani responden lebih menyukai benih lada putih varietas Petaling 1 dibandingkan dengan benih lada putih varietas Merapen dan LDK. Hal ini menunjukan bahwa benih lada putih varietas petaling 1 secara keseluruhan mempunyai keunggulan antara lain pada atribut produktivitas, ketahanan terhadap penyakit kuning, jenis varietas benih, label benih, jumlah ruas benih dan ketersediaan demplot. Sehingga secara umum petani telah mengetahui dan memahami keunggulan dan kelemahan dari benih lada putih varietas Petaling 1, LDK dan Merapen.

Setelah melakukan penggunaan terhadap benih lada putih akan terbentuk persepsi dalam diri petani responden. Petani responden memiliki persepsi yang berbeda-beda pada masing-masing atribut. Berdasarkan hasil penelitian, secara keseluruhan persepsi petani responden terhadap benih lada putih varietas petaling 1 lebih baik dibandingkan dengan benih lada putih varietas merapen dan LDK. Varietas Petaling 1 unggul di atribut produktivitas, ketahanan terhadap penyakit kuning, jenis varietas, label (sertifikasi) benih, jumlah ruas benih dan ketersediaan demplot. Namun atribut harga dan ketahanan terhadap penyakit busuk pangkal batang rendah. Meskipun dari atribut harga benih, varietas petaling 1 lebih mahal harganya dibandingkan varietas LDK dan merapen namun hal tersebut tidak mengurangi persepsi petani terhadap kualitas benih varietas petaling 1 . Salah satu faktor utama petani untuk menggunakan benih lada putih varietas petaling 1 yaitu produktivitasnya yang tinggi dan disertai dengan

Tabel 2

Analisis sikap petani terhadap benih lada.

\begin{tabular}{llll}
\hline Atribut & Petaling 1 & LDK & Merapen \\
\hline
\end{tabular}




\begin{tabular}{|c|c|c|c|c|c|c|c|}
\hline & $\begin{array}{l}\text { Skor } \\
\text { evaluasi }\end{array}$ & $\begin{array}{l}\text { skor keper- } \\
\text { cayaan }\end{array}$ & sikap (A0) & $\begin{array}{l}\text { skor keper- } \\
\text { cayaan }\end{array}$ & sikap (A0) & $\begin{array}{l}\text { skor keper- } \\
\text { cayaan }\end{array}$ & sikap (A0) \\
\hline & ei & bi & ei*bi & bi & ei*bi & bi & ei*bi \\
\hline Produktivitas & 4.85 & 4.60 & 22.31 & 4.15 & 20.13 & 3.38 & 16.39 \\
\hline Ketahanan terhadap penyakit & & & & & & & \\
\hline kuning & 4.83 & 3.52 & 17.01 & 2.20 & 10.63 & 3.42 & 16.05 \\
\hline Ketahanan terhadap penyakit busuk & & & & & & & \\
\hline pangkal batang & 4.80 & 2.52 & 12.10 & 3.25 & 15.60 & 3.42 & 16.42 \\
\hline Stok benih (ketersediaan) & 4.60 & 4.53 & 20.84 & 3.95 & 18,17 & 4.55 & 20.93 \\
\hline Jenis varietas & 4.40 & 4.35 & 19.14 & 4,10 & 18,04 & 4.13 & 18.17 \\
\hline Umur panen(mulai produksi) & 4,23 & 4,12 & 17,44 & 4,17 & 17,65 & 3,90 & 16,51 \\
\hline Daya tumbuh & 3,85 & 3,48 & 13,40 & 3,45 & 13,28 & 3.52 & 13,55 \\
\hline Kemudahan dalam memperoleh & & & & & & & \\
\hline akses benih & 3,78 & 3,52 & 13,31 & 3,48 & 13,15 & 3,73 & 14,10 \\
\hline Harga benih & 3,65 & 3,30 & 12,05 & 3,42 & 12,48 & 3,65 & 13.32 \\
\hline Label benih & 3,42 & 3,37 & 11,53 & 3,27 & 11,18 & 2.58 & 8,82 \\
\hline Jumlah ruas benih & 3,20 & 3,18 & 10,18 & 3,08 & 9,86 & 2,98 & 9,54 \\
\hline Ketersediaan demplot & 3,17 & 3,12 & 9,89 & 3,03 & 9,61 & 2.58 & 8,18 \\
\hline Jumlah daun benih & 2,82 & 2,67 & 7,52 & 2,58 & 7,27 & 2,53 & 7,13 \\
\hline Tanggal kadaluarsa & 2,63 & 2,62 & 6,86 & 2,60 & 6,80 & 2,23 & 5,84 \\
\hline A0 Total (ei*bi) & & & 193.56 & & 183,86 & & 184,94 \\
\hline
\end{tabular}

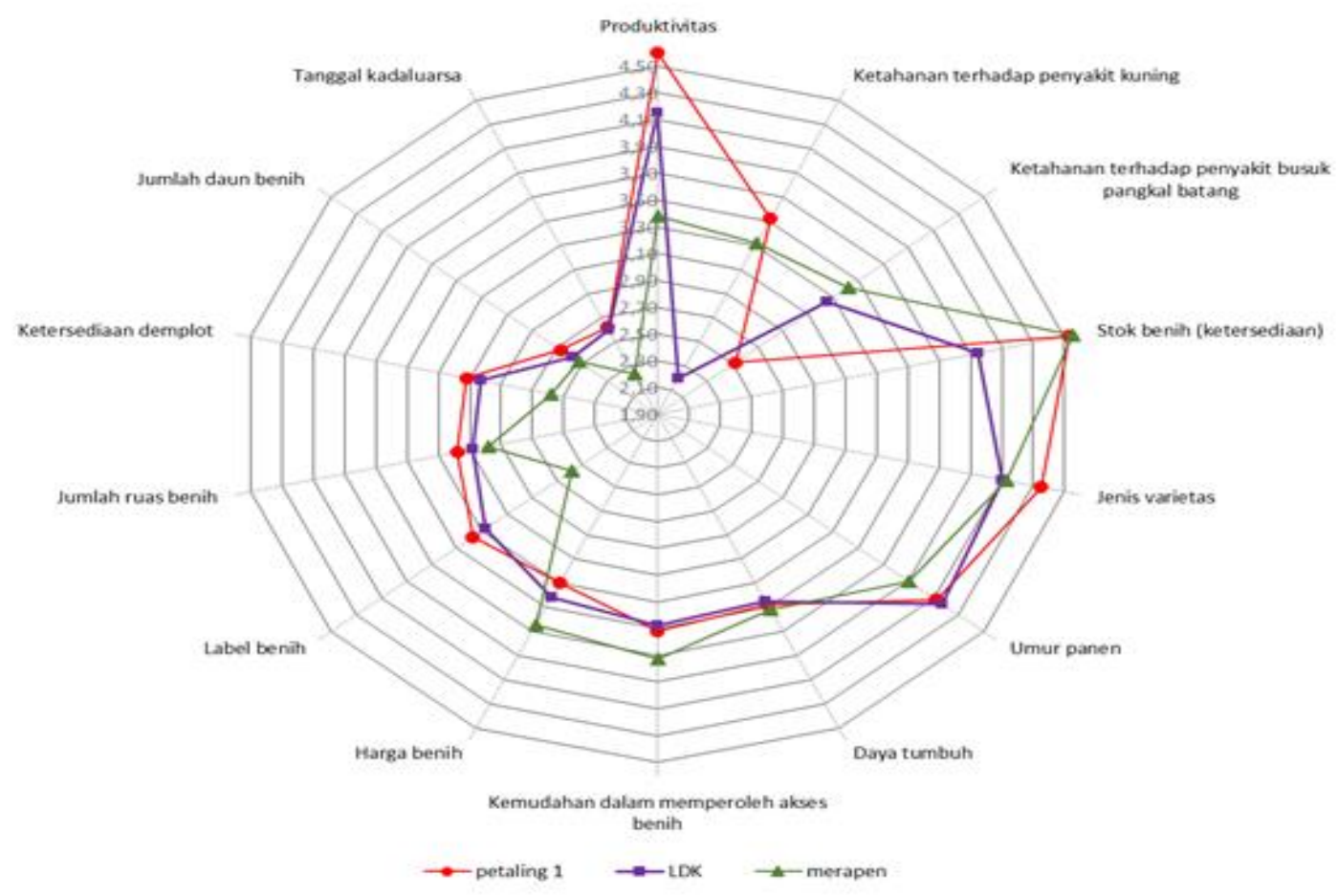

Gambar 1.

Peta persepsi sikap petani responden berdasarkan atribut terhadap benih lada varietas Petaling 1, LDK dan Marepan

ketahanan terhadap penyakit kuning. Sehingga diharapkan potensi produksi yang lebih besar dapat meningkatkan keuntungan yang lebih banyak dan membuat petani lada putih lebih sejahtera.

\section{KESIMPULAN DAN SARAN}

Kesimpulan yang dapat ditarik berdasarkan hasil dan pembahasan dari penelitian ini adalah :

1. Hasil analisis sikap dengan menggunakan multiatribut fishbein menunjukan bahwa secara keseluruhan benih lada putih varietas petaling 1 memperoleh nilai yang lebih tinggi. Hal ini menunjukan bahwa 
sikap petani responden lebih menyukai benih lada putih varietas Petaling 1 dibanding varietas merapen dan LDK.

2. Berdasarkan peta persepsi petani, atribut unggul Petaling 1 yaitu produktivitasnya yang tinggi, tahan terhadap penyakit kuning, label (sertifikasi) benih, jumlah ruas benih, jenis varietas dan ketersediaan demplot. Atribut yang dinilai rendah yaitu kurang tahan terhadap penyakit busuk pangkal batang dan harganya mahal.

Berdasarkan hasil penelitian, maka beberapa saran yang dapat direkomendasikan yaitu :

1. Rekomendasi kepada pemerintah agar membuat program penggunaan benih lada putih varietas petaling 1 di Provinsi Kepulauan Bangka Belitung, baik melalui sosialisasi maupun pengadaan benih.

2. Pemerintah dan pihak terkait diharapkan dapat meningkatkan atribut ketahanan terhadap penyakit busuk pangkal batang dan menurunkan harga benih varietas Petaling 1 .

\section{DAFTAR PUSTAKA}

Daras U, Pranowo D. 2009. Kondisi kritis lada putih Bangka Belitung dan alternatif pemulihannya. Jurnal Litbang Pertanian. 28(1):1-6.

Dinas Pertanian, Perkebunan dan Peternakan. (2016). Statistik Perkebunan Tahun 2015. Pangkalpinang (ID): Dinas Pertanian, Perkebunan dan Peternakan Provinsi Kepulauan Bangka Belitung.

[Ditjenbun]. 2014. Pedoman Teknis Budidaya Lada yang baik (Good Agricultural Practices for Pepper). Jakarta (ID) : Direktorat Jenderal PerkebunanKementerian Pertanian

Engel J F, Blackwel R D, Miniard P W. 1994. Perilaku Konsumen jilid I. Bina Aksara. Jakarta

[FAOSTATS] Food and Agriculture Organization Statistics. 2017. Exports, Production and Area Pepper (piper spp.). http://www.fao.org/faostat/ en/\#data/QC. [18 April 2017]

Hadad M E, Ferry Y. 2011. Pengembangan Industri Benih Jambu Mete Sirkuler, Teknologi Tanaman Rempah dan Industri. $22 \mathrm{hlm}$.
Harni R, Munif A. 2012. Pemanfaatan agens hayati endofit untuk mengendalikan penyakit kuning p/ada tanaman lada. Buletin Riset Tanaman Rempah Dan Aneka Tanaman Industri. 3(3):201-206.

Manohara, D. dan M. Machmud, 1986. Proses infeksi Phytophthora palmivora (Butl.) pada daun lada (Piper nigrum L.). LPTI. 11:60-66.

Mappiare. 1983. Psikologi Orang Dewasa. Surabaya: Usaha Nasional

Mislini. 2006. Analisis Jaringan Komunikasi pada Kelompok Swadaya Masyarakat. Kasus KSM di Desa Taman Sari Kabupaten Bogor, Provinsi Jawa Barat. [tesis], Bogor; Program Pascasarjana, IPB.

Mulya, K., Manohara, D. dan Herawati, 1986. Kemungkinan Terbawanya Phytophthora palmivora oleh setek lada dan 
penyediaan bibit sehat dengan perlakuan fungisida. Risalah seminar Ilmiah PFI.

Gatra Penelitian Penyakit Tumbuhan

dalam Pengendalian secara Terpadu.

Mulya K. Manohara D. Wahyuno D. 2003.

Status penyakit busuk pangkal batang lada

di Bangka. Risalah Simposium Nasional

Penelitian PHT Perkebunan Rakyat.

Bogor, 17-18 September 2003

Pusat Data dan Sistem Informasi Pertanian.

2015. Outlook Lada. Sekretariat Jenderal-Kementerian Pertanian. ISSN 1907-1507.

Rusyadi Y. 2014. Analisis Sikap dan Kepuasan Petani Terhadap Atribut Benih Padi Hibrida Maro di Kabupaten Subang Jawa Barat. [tesis]. Bogor (ID). IPB

Saefudin. 2014. Tantangan dan Kesiapan Teknologi Penyediaan Bahan Tanam Mendukung Peningkatan Produktivitas Nasional Tanaman Lada. Jurnal Perspektif Vol. 13. Jakarta

Sudjarmoko, B. 2013. Peran strategis industri benih dalam gerakan nasional peningkatan produktivitas karet di Indonesia. Medkom Perkebunan.

Wahyudi A, Hasibuan A M. 2011. Faktorfaktor yang mempengaruhi adopsi teknologi lada di kabupaten Belitung. Buletin Riset Tanaman Rempah dan Aneka Tanaman Industri 2(1): 65-74 
Vol. 2, No. 2, Desember 2017: 291-357 AGRICORE-Jurnal Agribisnis dan Sosial Ekonomi Pertanian 